\title{
Tipologi Politik Luar Negeri Indonesia Di Era Reformasi
}

\author{
Bambang Wahyu Nugroho \\ Jurusan IImu Hubungan Internasional, Fakultas IImu Sosial dan IImu Politik, \\ Universitas Muhammadiyah Yogyakarta \\ Ringroad Barat Tamantirto, Kasihan, Bantul 55183 \\ Email: bwnugie@hotmail.com
}

\begin{abstract}
In the limited capacity of post-independence economic and military, various implementation of Indonesia's foreign policies also be welcomed and got strong support from the power of the masses. But in the course of history, due to elitism in the Soeharto era, made foreign policy to be elitisized. Influence from people muted. The policies were run almost personally by President Suharto so that Indonesia's foreign policy became uninstitutionalized. The changes of political system in the Reformasi era (reforms) since the fall of President Suharto created opportunities to reformulate and to institutionalize Indonesia's foreign policy.

Meanwhile, during the first decade of Reform era in Indonesia (1998-2008) world political scene has undergone many changes and dynamics that presents opportunities and challenges toward Indonesia's foreign policy, particularly the transformation of economic globalization and international issues. Ambiguity of Indonesia's foreign policy profile at the beginning of the Reformasi era became an intellectual challenge, namely how to explain the "profile" that often be simplified as just "no-profile". Reforms provides an opportunity to the spirit of populism to back in, however the implementation of Indonesia's foreign policy sometimes seems elitist. It's a challenge for scientific analysis. Therefore, this work also specifically describes the factors forming the profile of implementation of Rl's foreign policy in the era of the Reform.

Keywords: free-and-active foreign policy, neoclassical realism, elitism, populism, international pressure, domestic alignment.
\end{abstract}

\begin{abstract}
Abstrak
Dalam kapasitas terbatas paska kemerdekaan ekonomi dan militer, berbagai macam pelaksanaan politik luar negeri Indonesia juga disambut baik dan mendapat dukungan kuat dari kekuatan massa. Namun dalam perjalanan Sejarah, dikarenakan elitisme pada era Soeharto, membuat politik luar negeri juga di elitisasi. Dipengaruhi oleh orang-orang yang diam. Kebijakan, hampir seluruhnya dilakukan secara personal oleh Soeharto, sehingga politik luar negeri Indonesia menjadi tidak terlembaga. Perubahan sistem politik di era reformasi sejak jatuhnya Presiden Soeharto menciptakan kesempatan untuk mereformasi ulang politik luar negeri Indonesia.

Sementara itu, pada dekade awal era reformasi di Indonesia (1998-2008) panggung politik dunia telah menyebabkan banyak perubahan dan dinamika yang memberikan kesempatan dan tantangan terhadap politik luar negeri Indonesia., khususnya transformasi pada globalisasi ekonomi dan isu internasional. Ambiguitas profil politik luar negeri Indonesia sesekali terlihat elitis. Ini merupakan tantangan untuk analisis ilmiah. Oleh karena itu, tulisan ini juga secara spesifik menggambarkan faktor pembentukan profil pada pelaksanaan politik luar negeri Republik Indonesia di era reformasi.
\end{abstract}

Kata Kunci: politik luar negeri bebas-aktif, neo-klasikal realisme, elitisme, populisme, tekanan internasioal, penjajaran domestik

\section{PENDAHULUAN}

Sejak proklamasi kemerdekaan 17 Agustus 1945, politik luar negeri Republik Indonesia (PLNRI) berprinsip bebas-aktif. Namun implementasi praktisnya mengalami perkembangan dari masa ke masa. Suatu kali tampak sangat low profile, lain waktu menjadi sangat assertive atau high profile, bahkan memasuki era Reformasi pasca lengsernya Presiden
Soeharti tahun 1988, profil PLNRI dipertanyakan kembali oleh para ahli. Dewi Fortuna Anwar secara normatif menguraikan apa yang seharusnya dilakukan oleh PLNRI setelah memasuki era Reformasi (Anwar, 2000). Namun, dalam kenyataannya, bertahun-tahun setelah itu PLNRI masih banyak dipersoalkan kembali. Mohtar Mas'oed menyebut PLNRI tak konsisten (The 
Jakarta Post, 26 Oktober 2000). Budiarto Shambazy menyebutkan bahwa PLNRI menunjukkan profil yang tidak jelas, bahkan disebut tak berprofil (no profile) (Kompas, 1 Juli 2001, hal. 25). Orientasinya pun dipertanyakan (Sihbudi, 2002) alias mengalami disorientasi.

Bahkan hingga tahun 2008 profil PLNRI masih dianggap tidak jelas sebagaimana pendapat berikut ini:

"Gaya politik luar negeri 'no profile' berpola acak mewarnai di semua periode kepemimpinan era Reformasi (sejak Habibie sampai dengan Susilo Bambang Yudhoyono [SBY])," bahkan di masa presiden Abdurrahman Wahid disebut "menabrak semua karang" dan di masa SBY didoktrinasi "mengarungi semua samudera" yang sampai saat ini belum jelas konseptualisasinya, lebih-lebih implementasinya." (Wuryandari, 2008)

Di era Orde Baru, PLNRI dikembangkan secara perlahan dari awalnya yang low profile menjadi lebih assertive sejak pertengahan tahun 1980-an seiring dengan meningkatnya kemakmuran ekonomi serta pergeseran penentu kebijakan dari militer ke presiden Soeharto sendiri (Sihbudi, 2002), sekalipun krisis ekonomi akut sejak akhir tahun 1988 berkembang menjadi krisis multidimensi yang melengserkan Soeharto. Bangsa Indonesia pun kemudian menata kembali sistem politiknya dengan gerakan Reformasi.

Krisis ekonomi dan perubahan besar-besaran dalam tatanan sistem politik dan pemerintahan di Indonesia pasca Orde Baru menjadikan politik luar negeri RI kembali inward looking (Anwar, 2000). Artinya, pemerintah RI lebih memprioritaskan penyelesaian masalah domestik, terutama krisis ekonomi beserta dampaknya. Oleh karena itu urusan genting yang berkaitan dengan kekuatan asing cenderung “dilepaskan." Peristiwa terlepasnya Timor Timur dan pulau Sipadan-Ligitan, misalnya, merupakan contoh efek dari inward looking tersebut.

Sementara itu dalam kurun satu dasawarsa era Reformasi di Indonesia (1998-2008) panggung politik dunia telah mengalami banyak perubahan dan dinamika yang menghadirkan peluang serta tantangan bagi politik luar negeri Republik Indonesia.

Kebangkitan ekonomi dan militer Cina menghadirkan tantangan baru bagi konstelasi ekonomi politik dunia yang semakin mengglobal. Kemudian, kasus-kasus terorisme internasional/transnasional yang salah satu puncaknya adalah peledakan gedung World Trade Center di New York tanggal 11 September 2001 (dikenal dengan istilah peristiwa 9/11) menimbulkan isu baru perang melawan terorisme. Disusul kemudian dengan pecahnya peperangan di Afghanistan dan Irak, tentu mengguncangkan kembali isu keamanan di kawasan Timur Tengah yang berimplikasi global. Demikian pula isu perubahan iklim mulai mencuat dan menjadi perhatian global. Semua itu merupakan isu-isu yang berkembang dan mengemuka berbarengan dengan proses reformasi Indonesia menyongsong awal abad ke-21.

Gerakan Reformasi tahun 1998 yang mengakhiri kekuasaan otoritarian presiden Soeharto selama 32 tahun itu membangkitkan kembali demokrasi liberal di Indonesia dalam format pemerintahan presidensial. ${ }^{1}$ Gerakan reformasi juga menuntut politik kenegaraan yang lebih demokratis dalam arti semakin kompetitif dan partisipatif, terutama untuk menghadapi situasi dunia yang berubah sebagaimana keterangan di atas. Kompetitif, maksudnya adalah memberikan ruang kontestasi politik yang bebas dan partisipatif berarti peningkatan peran serta warga yang semakin luas dan semakin leluasa untuk mendukung demokratisasi politik dan berkontribusi mempengaruhi proses pembuatan keputusan politik, termasuk politik luar negeri.

Dengan demikin tugas ilmiah dalam karya ini adalah memaparkan bagaimana ragam profil implementasi politik luar negeri Republik Indonesia di era Reformasi dengan menggunakan kerangka berpikir yang memadai agar identifikasinya tidak lagi berakhir dengan sebuah negasi.

\section{METODOLOGI}

Tiga bingkai analisis yang akan digunakan dalam menjelaskan sebab dan proses sebagaimana dijadikan rumusan permasalahan di atas, yakni: 
a) Teori perimbangan ancaman (balance of threat theory) oleh Stephen Walt (1987);

b) Argumen perimbangan kepentingan (balance of interest argument) menurut Randall L. Schweller (1998); dan,

c) Model mobilisasi politik (political mobilization model) oleh Thomas Christensen (1996).

Menurut Walt, niat agresif suatu negara terhadap negara lain tentu bertingkat-tingkat, mulai dari sekadar interferensi (komentar negatif, campur tangan atau tekanan diplomatik terhadap kebijakan domestik), intervensi (embargo, boikot atau ancaman penggunaan kekerasan), hingga invasi (serbuan militer sesungguhnya). Sekalipun berbeda tingkatannya namun ketiganya dapat digolongkan sebagai tekanan internasional. Namun reaksi terhadap tekanan tersebut dapat dijelaskan lebih baik dengan model perimbangan kepentingan karya Schweller dengan mempertimbangkan aspek-aspek non struktural seperti karakter kepemimpinan elit maupun tanggapan publik terhadap kebijakan luar negeri. Pada gilirannya, penyelarasan antara kepentingan elit dan kepentingan publik akan menjadi variabel yang berpengaruh terhadap kebijakan luar negeri setelah elit mempertimbangkan kepentingannya vis a vis tekanan internasional.

Untuk memperjelas posisi penyelarasan antara kepentingan elit dan publik, digunakan model mobilisasi politik yang dikemukakan oleh Christensen. Pada intinya model ini mengasumsikan adanya keperluan elit pemimpin suatu negara untuk memobilisasi warganya dengan maksud mencari dukungan bagi kebijakannya yang tidak populer (non populis).

Ketiga alat bantu teoritik tersebut termasuk dalam kluster pendekatan realisme neoklasik yang dalam satu dasawarsa ini mengemuka sejak tulisan Gideon Rose (1998) hingga yang mutakhir oleh Steven Lobell dkk (2009) di awal tahun 2009. Pendekatan realisme neoklasik dipandang cukup mumpuni untuk menjawab kritik terhadap kekurangan realisme klasik maupun neorealisme.

Persoalan penyelarasan domestik lebih relevan diterapkan di dalam rezim demokrasi atau yang tengah melakukan demokratisasi, sebab peluang bagi diserapnya aspirasi dan partisipasi massa menjadi penting untuk dipertimbangkan. Di dalam rezim otoritarian, biasanya penguasa tidak memiliki saluran protes massa dalam merumuskan atau menanggapi kebijakan luar negeri, kecuali dalam hal sang pemimpin memerlukan mobilisasi dukungan massa. Di samping itu, penyelarasan domestik menjadi signifikan dalam beberapa kondisi sebagai berikut: (1) intensitas tekanan internasional lemah atau tidak ada; dan (2) tekanan internasional tidak kompatibel dengan kepentingan elit pemerintah, namun selaras (kompatibel) dengan tuntutan atau reaksi massa. Tentu saja apabila faktor internasional selaras dengan kepentingan elit domestik, maka tekanan internasional menjadi tidak diperlukan. Sedangkan penyelarasan juga tidak diperlukan dalam hal kepentingan elit sudah selaras dengan kepentingan massa. Hasilnya, profil politik luar negeri yang dihasilkan dari kombinasi tersebut akan disebut populis dan non-populis.

Tekanan internasional disebut kuat apabila terdapat teks yang muatan atau content-nya bermakna interferensi, intervensi, atau bahkan invasi yang dapat diinterpretasikan sebagai tuntutan internasional agar Indonesia melakukan atau tidak melakukan sesuatu. Ini disebut tekanan struktural Tekanan internasional juga dapat ditunjukkan dengan adanya kebijakan atau perubahan kebijakan negara asing atau sistem internasional yang konsekuensinya menimbulkan kerugian bagi Indonesia. Ini disebut tekanan sistemik.

Secara fragmentatif, tekanan internasional digolongkan lemah apabila kebijakan luar negeri RI tidak mendapatkan tanggapan negatif yang spesifik atau justeru mendapatkan dukungan dari pemerintah negara asing. ${ }^{2}$ Dari keterangan di atas, intensitas tekanan internasional dapat menjadi variabel independen yang menentukan profil PLNRI, dikontrol oleh variabel intervening berupa keselarasan antara elit dengan kepentingan massa.

Kerangka konseptual pembentuk ragam profil PLNRI dapat diilustrasikan sebagai berikut: 


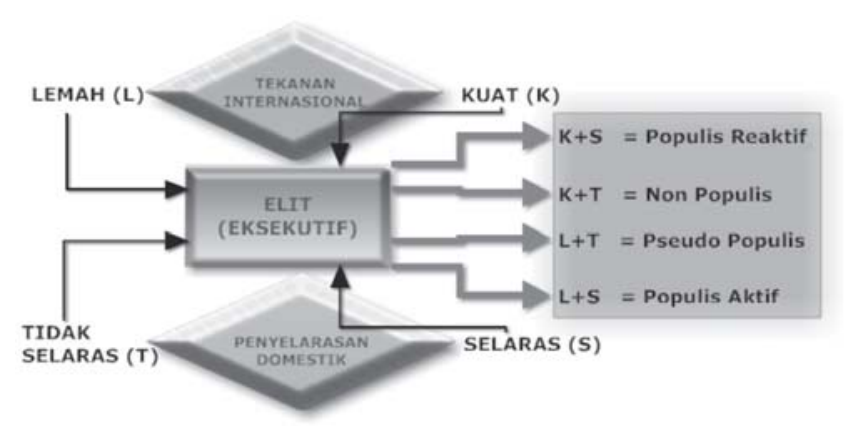

Gambar 1. Bagan alir proses pembentukan profil PLNRI di era Reformasi

Sedangkan skema tipologisnya sebagai berikut:

Tabel 1. Tipologi PLNRI

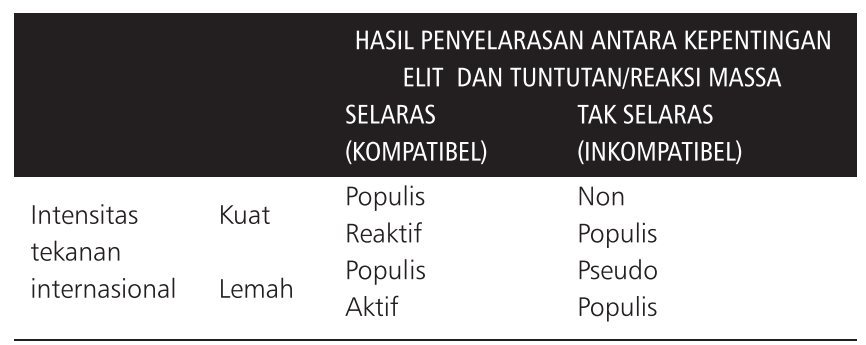

Artinya, dalam tekanan internasional yang kuat, semakin tidak selaras kepentingan elit dan massa, PLNRI semakin tidak populis; dan dalam tekanan internasional yang lemah, semakin tidak selaras kepentingan elit dan massa, populisma PLNRI semakin semu.

Metode analisis yang digunakan dalam karya ini yakni analisis teks dan wacana (Titcher dkk, 2009). Salah satu metodenya ialah analisis isi (content analysis) (Babbie, 1983:272-302). Di sini, opini massa dipandang merupakan produk wacana dalam masyarakat yang dikomunikasikan dan dipancarluaskan melalui sarana publik (http://en.wikipedia.org/wiki/ Public_opinion). Saya memilahnya menjadi dua hal, yakni: tuntutan dan reaksi massa. Tuntutan massa adalah aspirasi yang disampaikan secara terbuka dalam berbagai bentuk ungkapan "unjuk rasa" dengan agenda yang jelas untuk memengaruhi pembuatan kebijakan luar negeri pemerintah (elit). Sedangkan reaksi atau respons massa adalah tanggapan post facto, setelah pemerintah melakukan sebuah kebijakan luar negeri. Data mengenai kedua hal tersebut diperoleh dari eksposenya di media massa sebagai sarana refleksi maupun konstruksi kepentingan massa.

\section{PEMBAHASAN}

IMPLEMENTASI TIPOLOGI POLITIK LUAR NEGERI INDONESIA DI ERA REFORMASI

Tipologi populisme dan elitisme di dalam karya ini akan diterapkan dalam konteks reformasi Indonesia yang membawa pelembagaan dan reinterpretasi terhadap PLNRI bebas aktif. Berdasarkan pendekatan realisme neoklasik, maka variabel-variabel yang akan terlibat di dalamnya yakni: (1) intensitas tekanan internasional sebagai variabel independen, dan (2) tingkat keselarasan antara kepentingan elit dan tuntutan dan/atau reaksi massa sebagai variabel intervening-nya. Kemudiankedua variabel independen tersebut akan dielaborasi sehingga parameterparameternya kemudian dapat ditentukan.

Intensitas tekanan internasional akan diukur dari analisis terhadap (a) muatan (content) pembicaraan langsung dalam pertemuan antarpemimpin pemerintahan atau pernyataan eksplisit maupun implisit dari pemimpin negara asing tentang suatu kebijakan yang harus dilakukan atau harus tidak dilakukan oleh pemerintah Indonesia; dan (b) kebijakan luar negeri negara asing atau lembaga asing yang berpotensi merugikan Indonesia apabila Indonesia melakukan sesuatu yang ditentang oleh negara atau lembaga tersebut atau tidak melakukan sesuatu yang dituntut oleh negara atau lembaga tersebut.

Sedangkan keselarasan(kompatibilitas) antara kepentingan elit dan kepentingan massa akan diukur dari dua aspek yakni (a) tuntutan massa untuk memengaruhi pembuatan kebijakan luar negeri, dan (b) respons/reaksi massa terhadap kebijakan luar negeri. Kedua aspek tersebut tercermin di dalam ekspose di media massa yang dipandang dapat mewakili refleksi maupun konstruksi kepentingan massa. 
Kedua variabel independen di atas dalam kombinasi kualitatif tertentu akan mempengaruhi profil populis politik luar negeri Republik Indonesia yang beragam, yakni populis-aktif,populis-reaktif, pseudo-populis, atau non-populis. Penjelasan atas faktor-faktor tersebut akan diaplikasikan pada kasuskasus kebijakan luar negeri RI di bawah kepemimpinan presiden-presiden RI di dalam dasawarsa pertama era Reformasi, masing-masing dipilih lima kasus yang signifikan dan relevan.

Mundurnya Soeharto dari panggung kekuasaan Indonesia di tahun 1998 tidak dengan serta-merta menghentikan karakter elitis PLNRI. Meskipun sistem politik berubah dengan adanya tuntutan reformasi, pada masa kepresidenan B.J. Habibie salah satu kasus yang dapat menunjukkan bahwa lembaga-lembaga negara seperti DPR-MPR maupun TNI tidak dilibatkan, yakni ketika Presiden B.J. Habibie mengambil keputusan memberikan opsi kemerdekaan bagi rakyat Timor Timur. Kebijakan ini mengejutkan hampir semua pemangku kepentingan PLNRI, termasuk Deplu sendiri. Hal semacam itu juga dilakukan oleh presiden berikutnya, Abdurrahman Wahid. Gagasannya untuk segera membuka hubungan dagang langsung dengan Israel tanpa mempertimbangkan opini para tokoh Muslim menjadikannya menuai protes keras dari kalangan ummat Islam dan tidak satupun yang membela gagasan tersebut. Bahkan gagasan pembentukan aliansi baru antara RRC, India, dan Indonesia dengan dukungan finansial dari Jepang dan Singapura ditengarai oleh Jusuf Wanandi sebagai ketidakpahaman Presiden Abdurrahman Wahid terhadap perkembanganperkembangan yang terjadi di bidang hubungan internasional, regional, serta "jelas tidak memakai keahlian dari Departemen Luar Negeri,” (Kompas, 1 Juli 2001).

Tidak diikutsertakannya Deplu memunculkan pertanyaan apakah gagasan tersebut akan dapat dilaksanakan. Meskipun tidak terungkap secara terbuka, namun orang-orang yang dekat dengan sumber keputusan itu menyiratkan adanya suasana frustrasi yang cukup besar. Sebagai sosok pemimpin yang demokratis sudah seharusnya presiden Abdurrahman Wahid juga meminta pendapat DPR, namun hal itu pun tidak dilakukannya. Ketiadaan atau sangat minimnya kerja sama dengan DPR berkonsekuensi pada minimnya dukungan DPR terhadap Presiden Abdurrahman Wahid. Apalagi protes massa yang diekspose oleh media massa, menjadi sangat kritis terhadap kebijakan-kebijakan luar negeri pemerintah Abdurrahman Wahid tersebut. ${ }^{3}$

Di masa kepresidenan Abdurrahman Wahid, misalnya, interpretasinya terhadap situasi internasional lebih intuitif/instinktif ketimbang berdasarkan keahlian. Menurut Ben Perkasa Drajat, Presiden Abdurrahman Wahid maupun Menlu Alwi Shihab bukanlah ahli di bidang politik luar negeri. Sekalipun begitu, keduanya tetap saja dipuji karena "keduanya memiliki instink yang akurat tentang peran potensial komunitas internasional dalam mendukung solusi krisis dan masalah nasional.” (Drajat, 2000)

Akibat menuruti naluri itu pula tampaknya Presiden Abdurrahman Wahid seperti semaunya sendiri melakukan kunjungan luar negeri ke berbagai negara tanpa didasarkan pada perencanaan yang matang. Kemudian melalui Menteri Pertahanan Mahfud M.D. mengusulkan pembentukan pakta pertahanan. Pelaksanaan PLNRI seperti itu mencerminkan ketiadaan kebijakan yang jelas karena apa yang hendak dicapai juga tidak jelas. Trias Kuncahyono mengomentari kondisi seperti itu dengan menyatakan bahwa PLNRI waktu itu sebagai policy of nonpolicy (Kuncahyono, 2001).

Walaupun tidak semencolok presiden Abdurrahman Wahid, namun presiden Megawati Soekarnoputri yang melanjutkan kepemimpinan Abdurrahman Wahid juga masih mengesankan elitisma perorangan tersebut. Sikapnya yang secara umum lebih banyak berdiam diri terhadap berbagai masalah negara yang penting, tiba-tiba Presiden Megawati Soekarnoputri memutuskan untuk melakukan kunjungan ke Korea Utara dengan maksud untuk membantu penyatuan kembali (reunifikasi) kedua Korea. Seperti bernostalgia atas keberhasilan ayahnya, presiden Soekarno, yang telah sukses 
menyelenggarakan KTT Asia Afrika tahun 1955, presiden Megawati Soekarnoputri juga sangat akrab dengan pemimpin RRC hingga membuahkan keputusan untuk menjual gas bumi blok Natuna secara jangka panjang dengan harga yang sangat murah kepada pemerintah RRC. Namun demikian, semua presiden tentunya kalau ditanyai tentang cara mereka menempuh kebijakan yang otoritarian itu, pasti mengatakan bahwa itu semua demi kepentingan nasional, kepentingan rakyat dan bangsa Indonesia. Artinya, mereka tetap menganggap diri mereka adalah tokoh yang populis dan PLNRI yang mereka bawakan juga berwajah populis. Padahal, elitisma PLNRI di era reformasi, sejauh itu, bukan sekedar elitisma oligarkis saja, namun bahkan didominasi oleh pemimpin tertinggi, yakni presiden. Semangat reformasi yang menuntut demokratisasi berubah arah kembali menjadi sekadar "penggantian sosok penguasa" atau "transplacement" (Huntington, 1995) sementara prosesnya sama saja dengan otoritarianisme Demokrasi Terpimpin di bawah presiden Soekarno maupun Orde Baru di bawah presiden Soeharto.

Dengan demikian jelaslah pada bagian ini bahwa setiap presiden sebagai top executive senantiasa memiliki kecenderungan pribadi dalam menafsirkan sekaligus keinginan mengimplementasikan PLNRI, apakah itu didasarkan pada ideologi, sejarah kehidupannya, maupun kepentingan-kepentingannya sendiri. Variabel inilah yang dirumuskan sebagai variabel kepentingan elit dalam proses pembentukan profil PLNRI. Dan dalam kasus Indonesia, hingga masa pemerintahan presiden Megawati Soekarnoputri, dominasi selera pribadi presiden sebagai "penafsir tunggal" kebijakan luar negeri masih terasa begitu jelas. Sementara pada periode kepemimpinan Susilo Bambang Yudhoyono, PLNRI lebih terlembaga, sekalipun tidak dapat benarbenar populis aktif sepenuhnya.

Ringkasnya, tindakan politik luar negeri sangat berpengaruh terhadap popularitas seorang presiden. Lepas dari prosentase kuantitatifnya, kebijakan luar negeri yang non populis akan mengakibatkan kemerosotan citra dan legitimasi seorang presiden. Dan oleh karena bagaimanapun politik luar negeri merupakan aktivitas elitis dan dilaksanakan oleh segelintir elit pemerintahan, maka kebijakan yang non populis akan segera menimbulkan kesan elitis bagi pelakunya karena dipandang tidak peduli dengan kepentingan rakyat banyak di lingkungan domestik. Tiga presiden sebelum Susilo Bambang Yudhoyono tidak berhasil mempertahankan popularitasnya di mata publik, sebagian karena pernah melakukan kebijakan luar negeri yang dipandang non populis. Sementara itu, sekalipun sering kali masih melakukan kebijakan pseudo populis, kepemimpinan presiden Susilo Bambang Yudhoyono tetap legitimated hingga ketika Pilpres 2009 tiba, Susilo Bambang Yudhoyono kembali terpilih secara meyakinkan sebagai presiden RI untuk masa jabatan kedua (2009-2014).

\section{KESIMPULAN}

Berdasarkan pendekatan realisme neoklasik yang dioperasionalisasikan ke dalam bingkai tipologi profil politik luar negeri, maka PLNRI di era Reformasi yang semula sekadar dicap no-profile, inkonsisten, atau disoriented, dapat dipetakan menjadi empat varian, yakni populis aktif, populis pasif, pseudo-populis (populis semu), dan non-populis.

Di era Reformasi, masa kepresidenan B.J. Habibie, Abdurrahman Wahid, dan kemudian Megawati Soekarnoputri (1999-2004) merupakan era transisi demokrasi, dari otoriterisme di masa Orde Baru menuju situasi politik yang semakin demokratis. Di masa tersebut, upaya pelembagaan PLNRI masih sering bersimpangan dengan sikap pribadi para presifden tersebut. Hal itu dicirikan dengan masih besarnya selera personal sang presiden dalam urusan luar negeri, padahal sistem dan iklim politik reformasi telah mengalami perluasan elit pengambil keputusan dengan siapa presiden harus melakukan koordinasi, terutama DPR dan Deplu. Ajang politik yang kompetitif, kebebasan pers, dan meningkatnya peran lembagalembaga non pemerintah juga menuntut kepala pemerintahan untuk senantiasa menyelaraskan kebijakan luar negerinya dengan opini massa yang tercermin dalam sorotan dan ekspose oleh media massa. 
Akibat dari situasi transisional tersebut maka seringkali presiden "terperangkap" melakukan kebijakan luar negeri dan aktivitas hubungan luar negeri yang populis reaktif atau non populis. Hal ini diakibatkan oleh kerumitan yang mereka alami karena menghadapi dua front, yakni intensitas tekanan internasional yang masih sangat kuat dan/atau front politik domestik dari mana kerap kali tuntutan atau reaksi massa bertentangan dengan kepentingan presiden. Di luar itu sering juga presiden melakukan kebijakan luar negeri yang berprofil pseudo populis, yang di permukaan tampak populis namun sesungguhnya menyembunyikan kepentingan elitisnya sendiri.

Sementara itu di masa kepemimpinan Presiden SBY (2004-2009), dalam kondisi tekanan internasional tidak begitu kuat, maka peluang SBY-JK untuk melakukan inisiatif yang menghasilkan profil PLNRI populis aktif lebih besar, sementara apabila intensitas tekanan internasional menguat, maka penyelarasan terhadap gap antara kepentingan elit dan dan kepentingan massa akan dikemas dengan sebuah penampilan kebijakan luar negeri berprofil populis semu (pseudo populis).

Aksi-aksi populisma politik luar negeri seperti pembelaan terhadap hak-hak warga negara Indonesia di luar negeri, khususnya tenaga kerja Indonesia (TKI) dan tenaga kerja wanita (TKW) memang tampak lebih nyata dan koordinatif. Tetapi yang harus dicermati yakni bahwa masalah TKI dan TKW hanyalah permukaan dari keterbatasan lapangan kerja dan di tanah air. Maka kebijakan "populis" itu akan menjadi sebuah populisme semu apabila persoalan yang lebih substansial, yakni hegemoni korporatokrasi penghasung kapitalisme liberal masih terus menguasai jantung perekonomian Indonesia.

\section{CATATAN AKHIR}

bukan parlementer sebagaimana demokrasi liberal pasca kemerdekaan RI 1945-1959.

2 Contoh kajian tentang tekanan internasional terdapat dalam Bambang Cipto, Tekanan Amerika terhadap Indonesia, Kajian atas Kebijakan Clinton terhadap Indonesia (Yogyakarta: Pustaka Pelajar, 2003), hal. 284-306.

3 Beberapa seminar dan di banyak tulisan para pengamat politik menyimpulkan PLNRI pada masa presiden Abdurrahman Wahid sebagai bukan high-profile maupun low-profile, melainkan noprofile.

\section{REFERENSI}

Albertazzi, Daniele dan Duncan McDonnell. 2008. Twenty-First Century Populism: The Spectre of Western European Democracy. New York and London: Palgrave Macmillan.

Anderson, Benedict.2001. Imagined Communities, Komunitaskomunitas Terbayang. Yogyakarta: Insist Press.

Aspinall, E., Van Klinken, G., Feith, H. (eds).1999. The Last Days of President Suharto. Monash University: Monash Asia Institute.

Babbie, Earl.1983. The Practice of Social Research. Belmont, Calif.: Wodsworth Publishing Co.

Cipto, Bambang.2003. Tekanan Amerika terhadap Indonesia, Kajian atas Kebijakan Clinton terhadap Indonesia. Yogyakarta: Pustaka Pelajar.

Bandoro, Bantarto (ed.). 1994. Hubungan Luar Negeri Indonesia selama Orde Baru. Jakarta: CSIS.

Betz, Hans-Georg.1994. Radical Right-wing Populism in Western Europe. New York: St. Martin's Press.

............., Buku Putih Politik Luar Negeri Indonesia. 2003. Jakarta: Departemen Luar Negeri RI.

Canovan, Margaret. 1981. Populism, New York and London: Harcourt Brace Jovanovich.

Hermann, Charles F., Charles W. Kegley Jr., and James N. Rosenau. (eds.). 1987. New Direction in the Study of Foreign Policy. Boston: Allen \&Unwin.

Christensen, Thomas. 1996. Useful Adversaries: Grand Strategy, Domestic Mobilization, and Sino-American Conflict, 1947-1958. Princeton, Princeton University Press.

Albertazzi,Danielle dan Duncan McDonnell. 2008. Twenty-First Century Populism: The Spectre of Western European Democracy. New York \& London: Palgrave Macmillan, 2008.

Anwar, Dewi Fortuna. 2000. Menggagas Politik Luar Negeri Indonesia Baru. Makalah tak diterbitkan. Jakarta.

Damian, Eddy dan Budiono Kusumohamidjojo (eds.).1983. Politik Luar Negeri Indonesia dan Pelaksanaannya Dewasa Ini, Kumpulan Karangan dan Pidato Mochtar Kusumaatmadja. Bandung: Alumni.

Efantino dan Arifin S.N. 2009. Ganyang Malaysia, Yogyakarta: Distributor Bukukita.

Europa World Year Book 2004. Edisi ke-45. 2006. Taylor \& Francis Group, Europa Publication.

Evans, Graham dan Jeffrey Newnham. 1998. The Penguin Dictionary of International Relations. London: Penguin Books.

Forrester, G. (ed.). 1999 Post Suharto Indonesia: Renewal or Chaos? Bathurst: Crawford House Publishing.

Wuryandari,Ganewati (ed.). 2008. Politik Luar Negeri Republik Indonesia di Tengah Pusaran Politik Domestik. Yogyakarta: Pustaka Pelajar.

Hamengku Buwono X. 2007. Merajut Kembali Keindonesiaan Kita. Jakarta: Gramedia.

Heywood, Andrew. 2007. Foundations Politics. London: Macmilan.

Hilsman, Roger. 2000. The Politics of Policy Making in Defense and Foreign Affairs, Conceptual Models and Bureaucratic Politics. Edisi 
ke-3.New Jersey: A Pearson Education Co.

Huntington, Samuel P.1995. Gelombang Demokratisasi Ketiga, Jakarta: Penerbit Pustaka Grafiti.

Arsana,I Made Andi. 2007. Batas Maritim Antar Negara, sebuah Tinjauan Teknis dan Yuridis. Yogyakarta: Gadjah Mada University Press.

Wijaya, I Wangsa dan Meutia F. Swasono (eds.). 1981. Mohammad Hatta: Kumpulan Pidato dari tahun 1942 s.d 1949. Jakarta: Yayasan Idayu.

Agung, Ide Anak Agung Gde. 1990. Twenty Years Indonesian Foreign Policy: 1945-1965. Yogyakarta: Duta Wacana University Press.

Bakti, Ikrar Nusa. 1998 "Kendala Internal dan Eksternal Diplomasi RI Soal Timor Timur," makalah Seminar tak diterbitkan. Jakarta.

Jackson, Robert dan George Sorensen. 2005. Pengantar Studi Hubungan Internasional. Yogyakarta: Pustaka Pelajar.

Kamus Besar Bahasa Indonesia. Edisi ke-3. (2005). Jakarta: Balai Pustaka.

Kazin, Michael. 1995. The Populist Persuasion: An American History. New York: Basic Books.

Kegley, Charles W. dan Eugene R. Wittkopf. Edisi ke-10. (2008). World Politics Trend and Transformations, Boston, Massachusetts: Thompson Wadsworth.

Kegley, Charles W. dan Eugene R. Wittkopf.1999. World Politics, Trend and Transformations. Edisi ke-7. Boston: Bedford/St. Martin's.

Keohane, Robert O. (ed.), 1986. Neorealism and its Critics. New York: Columbia University Press.

King, Gary, Robert O. Keohane dan Sidney Verba. 1994. Designing Qualitative Inquiry: Scientific Inference in Qualitative Research. New Jersey: Princeton University Press.

Kitschelt, Herbert dan Anthony McGunn. (1995). The Radical Right in Western Europe. A Comparative Analysis. Ann Arbor: University of Michighan Press.

Kusnanto Anggoro.2000. Visi dan Orientasi Politik Luar Negeri Indonesia di bawah Pemerintahan Abdurrahman Wahid. Makalah tak diterbitkan. Jakarta.

Gie, Kwik Kian. 2009. Indonesia Menggugat Jilid II. Jakarta: Gramedia.

Laclau, Ernesto. 1985. On Populist Reason. London: Verso.

Leifer, Michael. 1983. Indonesia's Foreign Policy. London: Allen \& Unwin.

Suryadinata, Leo.1996. Indonesia's Foreign Policy under Soeharto. Singapore: Times Academic Press.

Lobell, Steven E., Norrin M. Ripsman dan Jeffrey W. Taliaferro (eds). 2009. Neoclassical Realism, The State, and Foreign Policy. Cambridge: Cambridge University Press.

Meny, Yves dan Yves Surel. 2002. Democracies and the Populist Challenge. London: Palgrave Macmillan.

Merriam Websters' Collegiate Dictionary. Edisi ke-10.2002. Springfield, Mass.: Merriam-Webster's Inc.

Hatta, Mohammad. 1981 Pengertian Pancasila. Jakarta: Yayasan Idayu. Sabir, Mohammad. 1987. Politik Bebas Aktif. Jakarta: Haji Masagung.

Mas'oed, Mohtar. 1990. Ilmu Hubungan Internasional, Disiplin dan Metodologi. Jakarta: LP3ES.

Rais, Muhammad Amien. 2008. Agenda Mendesak Bangsa: Selamatkan Indonesia. Yogyakarta: PPSK Press.

Neuman, Stephanie G. (ed.).1998. International Relations Theory and the Third World (Hampshire \& London: Macmillan.
Plano, Jack C., dan Roy Olton. 1978. The International Relations Dictionary. New York: Holt, Rhinehart and Winston.

Purwadi. Kamus Jawa-Indonesia Indonesia-Jawa. 2005. Yogyakarta: Bina Media.

Restrukturisasi Departemen Luar Negeri ke arah Peningkatan Efektivitas Diplomasi Global di Abad XXI. Jakarta: Balitbang Departemen Luar Negeri RI.

Rizal Sukma. Indonesia and China: The Politics of Troubled Relationship. 1999. London and New York: Routledge.

Rosenau, James N. (ed.). International Politics and Foreign Policy. 1969. New York: Free Press.

Russett, Bruce dan Harvey Starr, World Politics, the Menu for Choice. Edisi ke-5. 1996. New York: Freeman \& Co.

Schwarz, Adam. (1999). A Nation in Waiting. Edisi ke-2. New South Wales: Allen-Unwin.

Schweller, Randall L. 1998. Deadly Imbalances: Tripolarity and Hitler's Strategy of World Conquest. New York: Columbia University Press.

Snyder, Richard C., H.W. Bruck dan Burton Sapin (eds.). 1963. Foreign Policy Decision Making. New York: The Free Press.

Solingen, Etel. 2007. Nuclear Logics: Contrasting Paths in East Asia and the Middle East. Princeton: Princeton University Press.

Stiglitz, Joseph E. 2006. Making Globalization Work. New York: W.W. Norton \& Company Inc.

Stoessinger, John G. 1990. The Might of Nations: World Politics in Our Time. Edisi ke-9. New York: McGraw-Hill.

Tabrani Rab. Menuju Riau Merdeka: Pilihan Kongres Rakyat Riau II. 2000. Pekanbaru: Dewan Perjuangan Kedaulatan Riau.

Taguieff, Pierre-Andre. 2002. L'illusion populiste, Paris: Berg International.

Titscher, Stefan, Michael Mayer, Ruth Wodak, dan Eva Vetter.2009. Metode Analisis Teks dan Wacana. Yogyakarta: Pustaka Pelajar.

Vasquez, John A. (ed.). 1990. Classics of International Relations. Edisi ke-2. New Jersey: Prentice-Hall.

Walt, Stephen. 1987. TheOrigin of Alliances. Itacha and London: Cornell University Press.

Waltz, Kenneth N.1958. Man, The State, and War. New York: Columbia University Press. 